\title{
Atypical Alexander disease with dystonia, retinopathy, and a brain mass mimicking astrocytoma
}

\author{
Keren Machol, MD, PhD, Joseph Jankovic, MD, Dhanya Vijayakumar, MD, Lindsay C. Burrage, MD, PhD, \\ Mahim Jain, MD, PhD, Richard A. Lewis, MD, Gregory N. Fuller, MD, PhD, Mingchu Xu, PhD, \\ Marta Penas-Prado, MD, Maria K. Gule-Monroe, MD, Jill A. Rosenfeld, MS, CGC, Rui Chen, PhD, \\ Christine M. Eng, MD, Yaping Yang, PhD, Brendan H. Lee, MD, PhD, Paolo M. Moretti, MD, \\ Undiagnosed Diseases Network, and Shweta U. Dhar, MD, MS
}

Neurol Genet 2018;4:e248. doi:10.1212/NXG.0000000000000248

Alexander disease $(\mathrm{AD})$ is an autosomal dominant progressive astrogliopathy caused by pathogenic variants in glial fibrillary acidic protein (GFAP). ${ }^{1}$ Clinical presentation of $\mathrm{AD}$ includes infantile $\mathrm{AD}$, characterized by psychomotor retardation, seizures, pyramidal signs, and megalencephaly; juvenile $\mathrm{AD}$, characterized by bulbar/pseudobulbar signs, hyperreflexia, lower limb spasticity, ataxia, loss of intellectual function, and macrocephaly; and adult-onset $\mathrm{AD}$, characterized by progressive bulbar symptoms, ataxia, palatal myoclonus, bladder dysfunction, and spastic paraparesis. ${ }^{1}$

\section{Clinical report}

The patient is a 35-year-old woman with progressive left hemidystonia, retinitis pigmentosa $(\mathrm{RP})$, and history of brain tumor. At age 8 years, she developed vision loss, limp, afferent pupillary defect, and optic disc edema. A pilocytic astrocytoma, World Health Organization grade I, was diagnosed and resected. At age 14 years, she developed gait abnormality and progressive left hemidystonia that responded well to botulinum toxin injections. She then developed bilateral optic disc fibrosis, bitemporal hemianopia, and bilateral posterior subcapsular cataracts and was diagnosed with $\mathrm{RP}$ at 22 years (figure, A-D). She also reported chronic constipation, functional megacolon, uterine leiomyomas, and dysphagia.

Family history includes nonconsanguineous unaffected parents. Physical examination showed relative macrocephaly, absent ocular horizontal and vertical pursuit, dysarthria, circumduction gait and left-sided arm dystonia, muscle atrophy, hyperreflexia, and ankle clonus. Brain MRI demonstrated a frontal resection cavity, cystic encephalomalacia, and fluctuating enhancement of the hypothalamus. At age 29 years, a new left middle cerebellar peduncle lesion was identified (figure, $\mathrm{E}$ and $\mathrm{F}$ ).

The patient was enrolled in the NIH Undiagnosed Diseases Network (UDN). Whole-exome sequencing (WES) for her and her mother was completed. Her father was deceased at the time of evaluation.

\author{
Correspondence \\ Dr. Dhar \\ dhar@bcm.edu
}



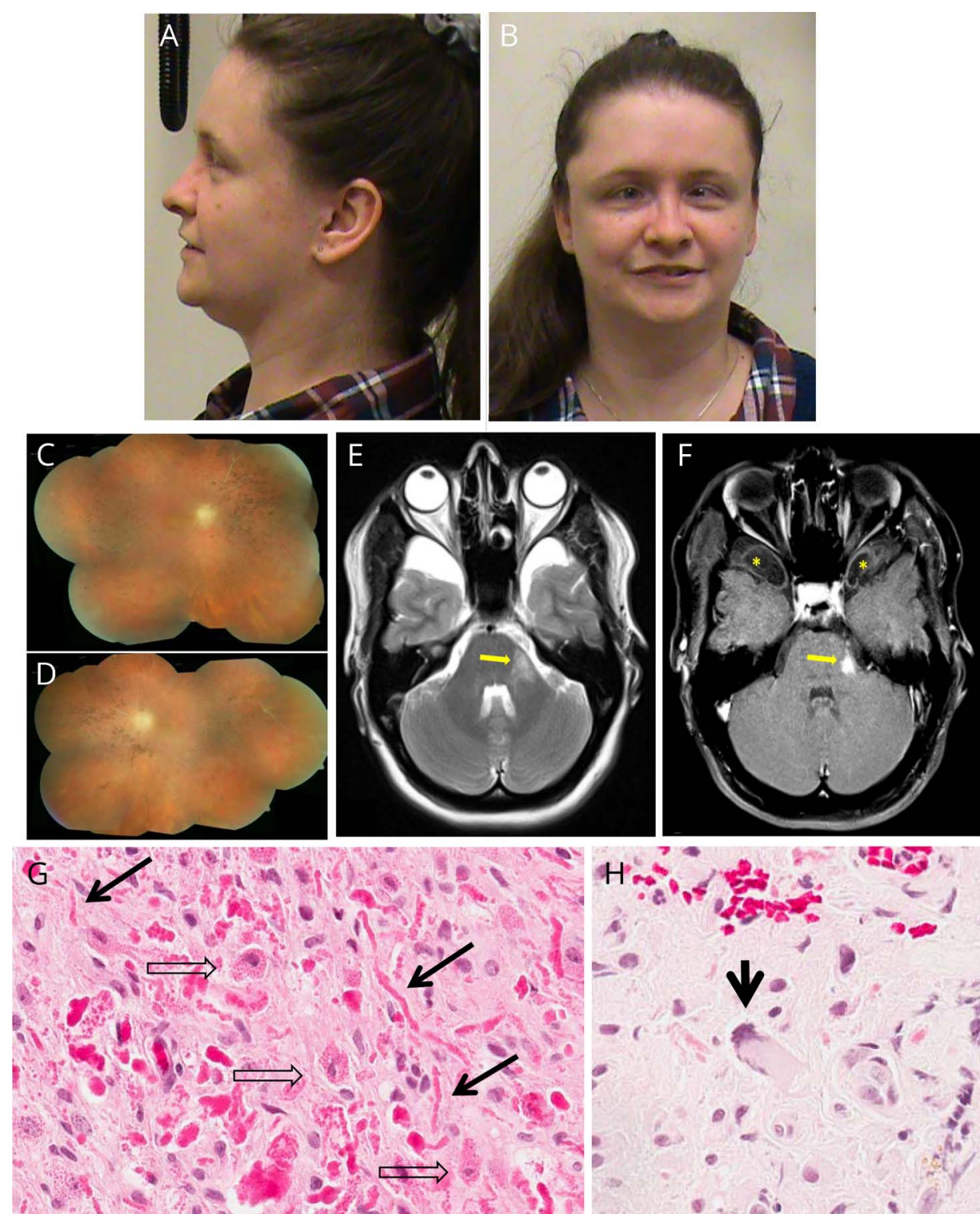

\section{Results}

WES revealed a novel heterozygous variant of uncertain significance (VUS) in GFAP (MIM 137780) c.989G $>$ C (p.R330P, NM 002055) and a heterozygous VUS c.6196G >A (p.D2066N, NM_006269) in RP1 (MIM_603937), both absent in the mother. The parental origin of the GFAP mutated allele could not be concluded based on WES data and available DNA samples. The variant in $R P 1$ was reported in 127 heterozygotes among 138,396 unrelated, unaffected individuals in gnomAD database (gnomad.broadinstitute.org). Both variants are predicted as damaging in SIFT (sorting intolerant from tolerant; sift.jcvi.org/) and Polyphen-2 (genetics.bwh. harvard.edu/pph2). No other contributory variants were detected in 256 known retinal disease genes.
A 35-year-old woman with juvenileonset Alexander disease (AD) (A and B). Note relative macrocephaly (FOC 56 $\mathrm{cm}$, 94th centile) and esotropia. The photomontage of the right (C) and left (D) eyes shows the atrophic gliosis from prior optic disc edema and the marked retinal atrophy and secondary pigmentary degeneration. The retinal vasculature appears to show glial sheathing and peripheral vaso-obliteration in each eye. Brain MRI with contrast at 29 years (E and F). (E) Axial T2 image demonstrates a T2 hyperintense lesion centered in the left middle cerebellar peduncle (yellow arrow). (F) Axial T1 image with contrast shows an area of central enhancement within the lesion (yellow arrow). Partially imaged is cystic encephalomalacia within the frontal lobes bilaterally (yellow asterisk) with surgical changes in the right frontal lobe not included. Slides from patient's brain lesion ( $G$ and $H$ ) demonstrating $A D$ histologic features. The prototypical histologic feature of $A D$ is prominent Rosenthal fiber formation (G, solid arrows). An additional feature unique to $A D$ is the presence of Rosenthal fiber-like eosinophilic cytoplasmic inclusions in astrocyte cell bodies ( $G$, open arrows). The cell body inclusions are generally not seen in other Rosenthal fiber-rich conditions such as low-grade primary brain tumors. Astrocytes with markedly atypical nuclei $(\mathrm{H}$, solid arrow) are also a characteristic morphologic feature of $A D$ and can mimic the neoplastic cells of astrocytoma or ganglioglioma. FOC = fronto-occipital circumference.
Pathology slides from the initial brain mass were re-examined. Histologic examination showed features of $\mathrm{AD}$, including profuse Rosenthal fiber formation, Rosenthal fiber-like eosinophilic cytoplasmic inclusions in astrocyte cell bodies, and scattered cells with markedly atypical nuclei (figure, G and H).

\section{Discussion}

Radiologic findings in $\mathrm{AD}$ vary with age at onset, and typical characteristics have been described for the various forms of $\mathrm{AD}$. Serial radiologic imaging of our patient showed sequelae of right frontal lobe resection, development of periventricular white matter changes, and fluctuating brainstem and hypothalamic lesions. Waxing and waning imaging findings, in the absence of treatment, were inconsistent with a brain tumor. 
Therefore, despite her previous diagnosis of a brain tumor, these new findings were interpreted as non-neoplastic, and the working diagnosis was non-MS demyelinating lesions. Similar atypical MRI findings had been described before in patients with molecularly proven $\mathrm{AD} .^{2}$ Dystonia and retinal abnormalities have never been previously reported with $\mathrm{AD}$. Left hemidystonia in our patient may be secondary to $\mathrm{AD}$ related encephalomalacia or a possible delayed consequence of right frontal brain resection. ${ }^{3}$ The RP1 VUS in our patient is less likely to be pathogenic, given the presence of multiple heterozygous carriers in population databases. It is unclear whether $\mathrm{RP}$ is a phenotypic expansion of $\mathrm{AD}$ or an unrelated finding (i.e., dual genetic diagnosis). ${ }^{4}$

Several histologic features of $\mathrm{AD}$ can mimic brain tumors. Rosenthal fiber formation in astrocytes of the brain and spinal cord, a pathologic hallmark of $\mathrm{AD}$, is also seen in several low-grade primary brain tumors (e.g., pilocytic astrocytoma, ganglioglioma, and pleomorphic xanthoastrocytoma). Cytologically atypical astrocytes, a recognized feature of $\mathrm{AD},{ }^{5}$ can also lead to misdiagnosis of pilocytic astrocytoma/ganglioglioma and unnecessary invasive interventions. The presence of Rosenthal fiber-like eosinophilic cytoplasmic inclusions in astrocyte cell bodies serves as a "red flag," raising the index of suspicion of $\mathrm{AD}$.

Over 120 pathogenic variants in GFAP have been reported with a possible dominant gain-of-function mechanism. ${ }^{6}$ GFAP p.R330P substitutes arginine, located in the evolutionarily wellconserved structure of GFAP, with proline. Another change in the same amino acid, p.R330G, was associated previously with adult $\mathrm{AD} .^{7}$ The potential functional significance of the p.R330P substitution, our patient's phenotype, and the histologic findings all strongly support GFAP p.R330P being a disease-causing variant.

Although relative macrocephaly, spasticity, ocular movement abnormalities, and autonomic disturbance (functional megacolon), as seen in our patient, have been described in juvenile $\mathrm{AD},{ }^{1}$ the diagnosis of $\mathrm{AD}$ was delayed because of an atypical presentation, including RP, left hemidystonia, atypical MRI findings, and histologic features confounding the diagnosis. This case emphasizes the clinical, histologic, and radiologic challenges in diagnosing $\mathrm{AD}$ and demonstrates the importance of considering $\mathrm{AD}$ in the differential diagnosis of specific Rosenthal fiber-rich brain lesions such as pilocytic astrocytoma.

\section{Author contributions}

$\mathrm{K}$. Machol: drafting the manuscript and analysis of wholeexome sequencing. J. Jankovic: neurologic management of the patient. D. Vijayakumar: drafting the manuscript. L.C. Burrage and M. Jain: analysis of whole-exome sequencing. R.A. Lewis: ophthalmologic evaluation of the patient and review and editing of the manuscript. G.N. Fuller: revision of histopathology and drafting the manuscript. M. Xu: review of RP-related genes in whole-exome sequence. M. Penas-Prado: oncologic management of the patient, drafting the manuscript, and critical revision of the manuscript. M. K. Gule-Monroe: radiology interpretation and drafting the manuscript. J. A. Rosenfeld: coordination of patient evaluation and critical revision of the manuscript. R. Chen: review of RP-related genes in whole-exome sequence. Y. Yang and C.M. Eng: analysis of whole-exome sequencing. B.H. Lee: critical revision of the manuscript. P.M. Moretti: neurologic evaluation of the patient and drafting the manuscript. S.U. Dhar: drafting the manuscript, critical revision of the manuscript, and patient management.

\section{Acknowledgment}

The authors thank the patient and her family for participating in this research. They thank Alyssa Tran, Deanna Erwin, and Alex Espana in the Molecular and Human Genetics Department, Baylor College of Medicine for administrative assistance.

\section{Study funding}

This work was supported by the BCM Intellectual and Developmental Disabilities Research Center (HD024064) from the NICHD and NIH/NHGRI U01 HG007709 Clinical Site for a UDN. The content is solely the responsibility of the authors and does not necessarily represent the official views of the NIH. The Department of Molecular and Human Genetics at Baylor College of Medicine receives revenue from clinical genetic testing offered by Baylor Genetics.

\section{Disclosure}

K. Machol reports no disclosures. J. Jankovic has served on the scientific advisory boards of, received gifts from, and received funding for travel or speaker honoraria from Adamas Pharmaceuticals Inc., Allergan Inc., and Teva Pharmaceutical Industries; has served on the editorial boards of Acta Neurologica Scandinavica, the Journal of Neurological Sciences, Neurology Medlink, Neurotherapeutics, Journal of Parkinson's Disease, and Toxins; receives publishing royalties from Cambridge, Elsevier, Future Science Group, Hodder Arnold, Lippincott Williams and Wilkins, and Wiley-Blackwell; and has received research support from Allergan Inc., CHDI Foundation, Civitas/Acorda Therapeutics, Dystonia Medical Research Foundation, Huntington Study Group, Ipsen Limited, Kyowa Haako Kirin Pharma Inc., Lundbeck Inc., Medtronic, Merz Pharmaceuticals, Michael J. Fox Foundation for Parkinson Research, NIH, National Parkinson Foundation, Parkinson Study Group, Pfizer, Prothena Biosicneces Inc., Psyadon Pharmaceuticals Inc., St. Jude Medical, and Teva Pharmaceutical Industries Ltd.; D. Vijayakumar reports no disclosures. L.C. Burrage has received funding for travel or speaker honoraria from the Burroughs Welcome, the NIH, and the Society for Inherited Metabolic Disorders and has received research support from the NIH/NIDDK, the NIH RDCRN, the Burroughs Welcome Fund, and the Ligums Family. M. Jain, R.A. Lewis, G.N. Fuller, and M. Xu report no disclosures. M. Penas-Prado has received funding for travel from AGIOS and LILLY and serves on the editorial board of Neuro-Oncology Practice. M.K. Gule-Monroe reports no 
disclosures. J.A. Rosenfeld serves on the editorial board of Prenatal Diagnosis and Molecular Syndromology and receives research support from the NIH/National Human Genome Research Institute. R. Chen has received research support from the NIH. C.M. Eng is employed by Baylor College of Medicine, which has a joint venture with Miraca Genetics Lab. Y. Yang reports no disclosures. B.H. Lee serves on the editorial advisory boards of the Journal of Clinical Investigation, Human Molecular Genetics, and the Journal of Bone Mineral Research and holds a patent license for helper dependent adenoviral gene therapy for osteoarthritis and phenylbutyrate use in Maple Syrup Urine Disease. P.M. Moretti received research support from the NHGRI/NIH. S.U. Dhar is employed by the Baylor College of Medicine, which has a joint venture with Miraca Life Services. Full disclosure form information provided by the authors is available with the full text of this article at Neurology.org/NG.

Received February 20, 2018. Accepted in final form May 14, 2018.

\section{References}

1. Prust $\mathrm{M}$, Wang J, Morizono $\mathrm{H}$, et al. GFAP mutations, age at onset, and clinical subtypes in Alexander disease. Neurology 2011;77:1287-1294.

2. Barreau P, Prust MJ, Crane J, et al. Focal central white matter lesions in Alexander disease. J Child Neurol 2011;26:1422-1424.

3. Wijemanne S, Jankovic J. Hemidystonia-hemiatrophy syndrome. Mov Disord 2009; 24:583-589.

4. Posey J, Harel T, Liu P, et al. Resolution of disease phenotypes resulting from multilocus genomic variation. N Engl J Med 2017;376:21-31.

5. Borrett D, Becker L. Alexander's disease: a disease of astrocytes. Brain 1985;108: 367-385.

6. Quinlan R, Brenner M, Goldman J, Messing A. GFAP and its role in Alexander disease. Exp Cell Res 2007;313:2077-2087.

7. Balbi P, Seri M, Ceccherini I, et al. Adult-onset Alexander disease. J Neurol 2007;255: 24-30. 


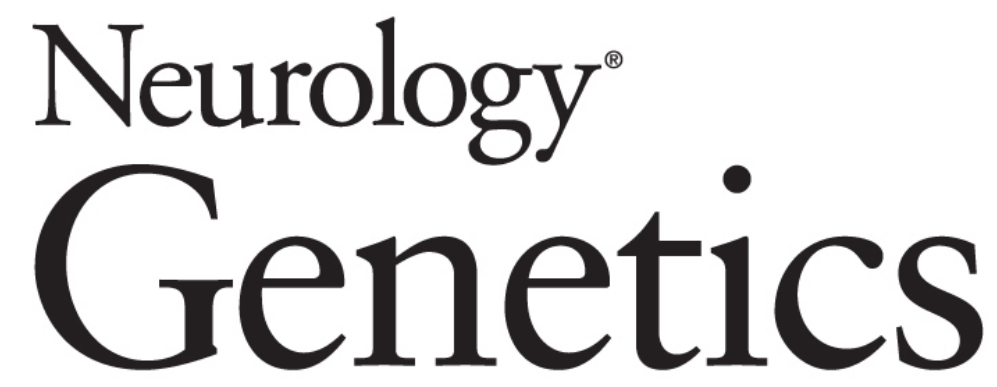

Atypical Alexander disease with dystonia, retinopathy, and a brain mass mimicking astrocytoma

Keren Machol, Joseph Jankovic, Dhanya Vijayakumar, et al. Neurol Genet 2018;4;

DOI 10.1212/NXG.0000000000000248

This information is current as of July 20, 2018

Neurol Genet is an official journal of the American Academy of Neurology. Published since April 2015, it is an open-access, online-only, continuous publication journal. Copyright Copyright ( 2018 The Author(s). Published by Wolters Kluwer Health, Inc. on behalf of the American Academy of Neurology.. All rights reserved. Online ISSN: 2376-7839.

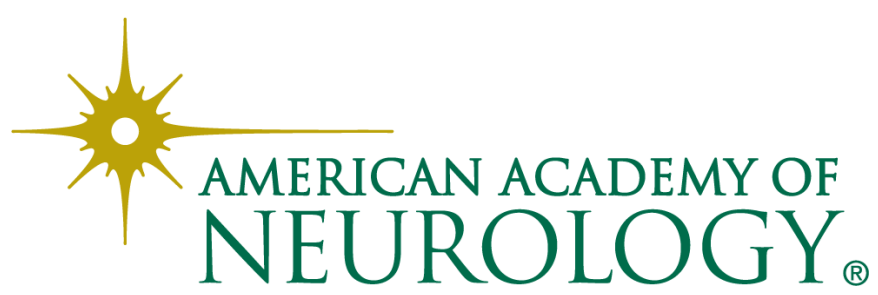




\section{Updated Information \& Services}

References

Citations

Subspecialty Collections

Permissions \& Licensing

Reprints including high resolution figures, can be found at: http://ng.neurology.org/content/4/4/e248.full.html

This article cites 7 articles, 0 of which you can access for free at: http://ng.neurology.org/content/4/4/e248.full.html\#\#ref-list-1

This article has been cited by 2 HighWire-hosted articles: http://ng.neurology.org/content/4/4/e248.full.html\#\#otherarticles

This article, along with others on similar topics, appears in the following collection(s):

All Clinical Neurology

http://ng.neurology.org//cgi/collection/all_clinical_neurology All Genetics

http://ng.neurology.org//cgi/collection/all_genetics

Dystonia

http://ng.neurology.org//cgi/collection/dystonia

Retina

http://ng.neurology.org//cgi/collection/retina

Information about reproducing this article in parts (figures,tables) or in its entirety can be found online at:

http://ng.neurology.org/misc/about.xhtml\#permissions

Information about ordering reprints can be found online:

http://ng.neurology.org/misc/addir.xhtml\#reprintsus

Neurol Genet is an official journal of the American Academy of Neurology. Published since April 2015, it is an open-access, online-only, continuous publication journal. Copyright Copyright $\odot 2018$ The Author(s). Published by Wolters Kluwer Health, Inc. on behalf of the American Academy of Neurology.. All rights reserved. Online ISSN: 2376-7839.

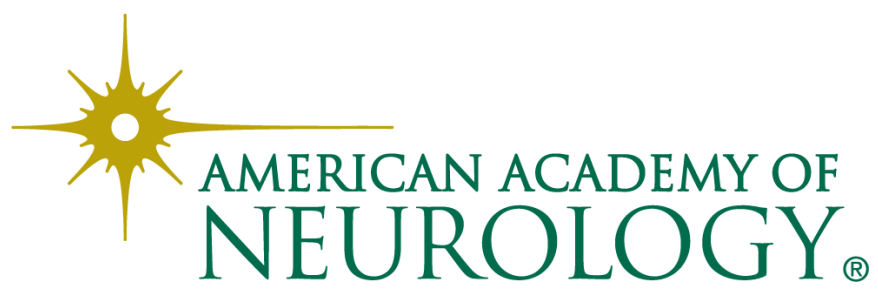

